\title{
Universiteit
}

Leiden

The Netherlands

\section{Between Exoticism and Silence. A Comparison of First Generation Migrant Writing in Germany and the Netherlands}

Minnaard, L.

\section{Citation}

Minnaard, L. (2011). Between Exoticism and Silence. A Comparison of First Generation Migrant Writing in Germany and the Netherlands. Arcadia: Internationale Zeitschrift Für Literaturwissenschaft, 46(1), 199-208. doi:10.1515/arca.2011.012

Version: $\quad$ Publisher's Version

License: $\quad$ Leiden University Non-exclusive license

Downloaded from: $\quad$ https://hdl.handle.net/1887/87362

Note: To cite this publication please use the final published version (if applicable). 


\title{
LIESBETH MINNAARD
}

\section{Between Exoticism and Silence \\ A Comparison of First Generation Migrant Writing in Germany and the Netherlands}

\begin{abstract}
There is a striking difference between the first appearance of literature of (labor) migration in German and in Dutch culture. In Germany, first-generation labor migrant writing appeared in the early 1980s, whereas writers of migration background (mostly of the second generation) entered Dutch culture only in the mid-1990s. The emergence of migrant writing in the two countries is examined in their specific socio-political contexts and their effect on contemporary German and Dutch literature of migration.
\end{abstract}

Language is an important topic in German and Dutch debates concerning multiculturality and migration. Acquiring the dominant language is now seen as a crucial tool, if not the first requirement, for a successful integration of migrant newcomers into the host societies. To emphasise language acquisition in matters of migration is a far cry from the once celebrated Dutch approach of "integration while retaining one's cultural identity", a policy that made the Netherlands famous for its (alleged) tolerance in encouraging and actually supporting migrants to foster their mother tongue. ${ }^{1}$ This policy took effect as early as 1983 , at a time when the political discussion in Germany still focused on possibilities of the return of the migrants to their countries of origin.

In my book New Germans, New Dutch. Literary Interventions (2008) on the imaginations of Dutch and German (national) identity in contemporary literature of migration, I perceive of the Dutch cultural pluralist policy of the 1980s and 1990s as an important and productive context - among others - for the selfconfident appropriation and re-imagining of Dutch identity. ${ }^{2}$ I contrast this

${ }^{1}$ This policy was severely criticised within the so-called "multicultural drama debate" of 2001 . The new realist discourse that gained prominence in the years following this debate completely discredited the policy. See Baukje Prins, Voorbij de onschuld. Het debat over integratie in Nederland, Amsterdam: Van Gennep, 2004.

${ }^{2}$ Liesbeth Minnaard, New Germans, New Dutch. Literary Interventions, Amsterdam: Amsterdam University Press, 2008. I use the popular but problematic term "migrant literature" to denote the writing of actual migrants. In this particular, comparative case the term migrant writing refers to the writing of first generation guest workers in Germany and the Netherlands. In all other cases I 
with the German situation, in which literature of migration of that period seems much more concerned with imagining national counter-identities or with rejecting national identity altogether.

This situation appears completely and amazingly different, however, when the focus of attention moves to an earlier period, to the literary production by first generation migrant writers. ${ }^{3}$ What we see here is a striking discrepancy between the first appearance of literature of migration in the German and in the Dutch literary fields. While several first-generation labour migrant writers appeared on Germany's literary scene in the early 1980s, in the Netherlands it was only during the 1990s that writers of labour migration background - mostly second generation - entered the Dutch cultural field in any considerable measure. ${ }^{4}$ Whereas in the Federal Republic of Germany (male) writers from various national backgrounds - Aras Ören, Rafik Schami, Franco Biondi, Yüksel Pazarkaya - published a range of literary writings during the 1980s, in the Netherlands there is only the one exception that confirms the rule of absence. The Turkish-Dutch writer Halil Gür, who published the two story-collections Gekke Mustafa (1984) and De hemel bleek grauw (1988), is the only writer of migrant background on the Dutch literary stage of the 1980s. ${ }^{5}$

In my opinion this difference demands and deserves further scrutiny. Why did migrant writing appear in the Netherlands 15 years later than that in Germany? Can a consideration of this discrepancy in the light of the choice for or against a cultural pluralist policy help to explain it? And can we detect traces of these different situations in contemporary literature of migration? To answer

use the term "literature of migration" as proposed by Leslie Adelson in her study The Turkish Turn in Contemporary Literature. Toward a New Critical Grammar of Migration, New York: Palgrave Macmillan, 2005.

${ }^{3}$ Nowadays this first generation of migrants is stereotypically represented as one that is unable to speak Dutch or German and that lives on the dole because of the health damage caused by the heavy physical labour that they performed. This image overshadows the fact that these labour migrants contributed in important ways to the German Wirtschaftswunder [economic miracle] and to the Dutch economic revival after World War II.

${ }^{4}$ For a more elaborate discussion of the appearance and development of literature of migration in the Dutch literary field see Liesbeth Minnaard, Effects of Migration in the Dutch Literary Field, in: Wolfgang Behschnitt, Sarah De Mul and Liesbeth Minnaard (eds.), Literature, Language, and Multiculturality in Scandinavia, the Netherlands, and Flanders, Amsterdam: Rodopi, forthcoming 2011.

${ }^{5}$ Halil Gür, Gekke Mustafa en andere verhalen, Breda: De Geus, 1985, and De hemel bleek graww, Breda: De Geus, 1988. The work of Halil Gür (that is originally written in English and then, in cooperation with Gür himself, translated into Dutch) appeared next to the literary writings of several postcolonial Dutch authors. This literature, however, constitutes a very different and specific category. In the Netherlands, it is important to emphasise the distinction between "migrant literature" as a cultural effect of labour migration and (post-)colonial literature. Although postcolonial writers in many cases have gone through processes of migration as well, huge differences in historical and social background necessitate a careful differentiation. 
these questions, I will first take a closer look at the emergence of migrant writing in the German and Dutch literary fields. Then I will turn to the specific sociopolitical contexts of the literary writings to see whether they provide possible explanations for the discrepancy. I will conclude with some remarks on the effect of these differences (and our perception of them) on current Dutch and German literature of migration.

\section{The appearance of "Guest Worker Literature" in Germany and the Netherlands}

As I have already mentioned, migrant writing or Gastarbeiterliteratur ("guest worker literature") as it was called at that time, appeared on the German cultural scene in the early 1980s. ${ }^{6}$ The 1981 publication of the programmatic article "Literatur der Betroffenheit. Bemerkungen zur Gastarbeiterliteratur" ("Literature of Being Moved. Remarks about Guest Worker Literature") (1981) by Franco Biondi (of Italian origin) and Rafik Schami (of Syrian origin), counts as an important early moment of visibility and speaking out. ${ }^{7}$ Biondi and Schami criticise the social situation of guest workers in German society and plead for a multi-national literature. In their opinion, "guest worker literature" should function as a form of cultural resistance. The publication of this article roughly coincided with the founding of the emancipatory society PoLiKunst-Verein (1980-87) and a publication series for foreign writers called "Südwind Gastarbeiterdeutsch" ("Southwind Guest Worker German"). As a politically inspired, multi-national collective, the PoLiKunst Society propagated a literature that fosters solidarity among workers of all nationalities.

At about the same time, a second group of advocates, which gathered around the Ararat Publishing House in Berlin, included Yüksel Pazarkaya and Aras Ören, both of Turkish background. They operated less as a group, but agreed that literature was an important source for intercultural exchange, mutual un-

${ }^{6}$ During the 1970s and 1980s the obscuring labels "guest workers" and "guest labour" were broadly used, despite their controversially discussed paradoxical, if not cynical, character: the awkward combination of guest and labour. Already in 1972 the radio broadcast company WDR organised a contest to find an alternative to the term. Despite 32,000 entries no proposal was accepted as appropriate. Nowadays the term counts as politically incorrect.

${ }^{7}$ Franco Biondi and Rafik Schami, Literatur der Betroffenheit. Bemerkungen zur Gastarbeiterliteratur, in: Christian Schaffernicht, $Z u$ Hause in der Fremde, Fischerhude: Atelier im Bauernhaus, 1981, pp. 124-135. In this article Biondi and Schami more or less open up the discussion on the most adequate terminology for literary work by writers of migrant background. They consciously use the 'stigma "guest worker"' (p. 135) as a self-referential epithet in order, as they explain themselves, to reveal the 'irony' inherent in the particular combination of guest and worker. Their use of the term Gastarbeiterliteratur is strategic and functions as a tool in a literary performance of social resistance. 
derstanding and even cultural synthesis. In his programmatic article of 1986, "Literatur ist Literatur" ("Literature Is Literature"), Pazarkaya explicitly dissociated himself from the term "guest worker literature" and from the sociopolitical demands made on literature by Biondi and Schami. ${ }^{8}$ According to Pazarkaya, such demands reduce literature to the level of manuals and cooking recipes, and neglect literature's main aesthetic dimension (pp. 62-63).

Again, another range of activities was organised by the Institute for German as a Foreign Language (IGFL) at the University of Munich. This Institute provided perhaps the most successful multicultural initiative in the German cultural field, by playing a prominent role in the promotion, dissemination and reception of "guest worker literature". In the early 1980s, the scholars Irmgard Ackermann and Harald Weinrich, both experts in the field of German as a Foreign Language, started organising a yearly writing contest for non-native German writers. Their engagement encouraged and supported labour migrants to produce writing in the foreign, German language. Besides, it enabled the publication of several anthologies with selected writing by Ausländer, "foreigners", to use their preferred term. ' Their efforts also raised a considerable amount of scholarly interest in the social and literary aspects of this new writing. Moreover, Ackermann and Weinrich established the "multicultural" Adelbert von Chamisso Prize for original works in the German language written by authors whose native language was not German. ${ }^{10}$

In the Dutch literary field of the 1980s, we find nothing similar: no manifestos, no writers' societies or multicultural publishing houses, and no literary works by "guest workers". The publishing house De Geus (in Breda) at that time already aimed for a multicultural collection, but, except for the mentioned Halil Gür, this included mainly foreign "multicultural" or "ethnic" literature in translation. One could argue that the E. du Perron Prize, established in 1986, can be considered as the Dutch equivalent of the Chamisso Prize, for it also aims to acknowledge and encourage the transformative process of multiculturalisation. However, the prize was not restricted to literature, and did not ask that the laureates have (ethnic) identity features. The prize rewards the positive social

${ }^{8}$ Yüksel Pazarkaya, Literatur ist Literatur, in: Irmgard Ackermann, Harald Weinrich, Eine nicht nur deutsche Literatur. Zur Standortbestimmung der "Ausländerliteratur", München, Zürich: Piper, 1986, pp. 59-64.

9 Two examples are the volumes Als Fremder in Deutschland. Berichte, Erzählungen, Gedichte von Ausländern (München, dtv: 1982) and In zwei Sprachen leben. Berichte, Erzählungen, Gedichte von Ausländern (München: dtv, 1983), both edited by Irmgard Ackermann. For a discussion of "Foreigners' literature" see Ackermann/Weinrich, Eine nicht nur deutsche Literatur (see note 8).

${ }^{10}$ Since 1984 the Robert Bosch Stiftung has annually awarded the Adelbert von Chamisso Prize; in 2009 the Prize celebrated its 25th birthday. For a discussion of this prize see Karl Esselborn, Der Adelbert-von-Chamisso-Preis und die Förderung der Migrationsliteratur, in: Klaus Schenk, Almut Todorow, Milan Tvrdík, Migrationsliteratur. Schreibweisen einer interkulturelle Moderne, Tübingen, Basel: Francke Verlag, 2004, pp. 317-325. 
effect of a certain cultural activity, and prize winners varied from individuals of diverse ethnic backgrounds (including autochthonous Dutch) to educative projects. ${ }^{11}$

The El Hizjra Prize is another Dutch initiative to encourage multiculturality, this time indeed restricted to literature. ${ }^{12}$ However, this prize was founded only in the early 1990s. In general, the publication of Mustafa Stitou's poetry collection Mijn vormen in 1994 is seen as the first literature of migration in the Netherlands. Stitou's poetry received a very positive welcome, obtained several literary awards and stirred public interest in work by writers of migrant background. But this happened in the 1990s, and neither Stitou nor the other writers that successfully entered the literary field at this time, came to the Netherlands as a "guest worker". ${ }^{13}$

In scholarship, we get very much the same picture. Also the scholarly discussion on "migrant literature" in the Netherlands developed quite a bit later than the discussion in Germany. A German Society for Intercultural Germanistics (Gesellschaft für interkulturelle Germanistik), founded as early as 1984, encouraged scholarly reflection on concepts such as identity and alterity, intercultural dialogue, and German multiculturality. In the same year, a special issue of the Germanist journal Zeitschrift für Literaturwissenschaft und Linguistik (LiLi) addressed the theme of "Guest Worker Literature" ("Gastarbeiterliteratur"). Again, we find nothing of the kind in Dutch academia. It is striking as well as telling that even the 1994 special issue of the journal Literatuur, "How Dutch is Dutch literature?" made no reference to the literary effects of migration or multiculturality. It discussed the Dutchness of Dutch literature because of the gradual unification of Europe (and the threat that this possibly poses to Dutchness), as if migrants or multiculturality were simply non-existent. Only in 1999 was Literatuur the first Dutch journal to devote an issue to the multicultural theme Literaturen in het Nederlands (Literatures in Dutch). ${ }^{14}$

${ }^{11}$ Halil Gür was the first to win prize in 1986. The next prizewinner of (labour) migrant background was Hafid Bouazza in 1996.

12 The El Hizjra writing contest is officially restricted to writers of Moroccan and Arab background writing in the Dutch, Arab or Tamazight language. The prize is considered an important spring board for writers of Arab background.

${ }^{13}$ Many of these writers belong to the so-called "one-and-a-half" generation: they have migrated to the Netherlands before their thirteenth birthday.

${ }^{14}$ Bert Paasman et al. (eds.), Literaturen in het Nederlands. Special of Literatuur 16, 1999, 6. 


\section{A Striking Discrepancy}

The work of the Munich Institute is often seen negatively in retrospect. The ideological thrust of its engagement is nowadays criticised as paternalistic and exoticist, for, indeed, it seems as well-meant but extremely patronising to the contemporary critic. ${ }^{15}$ The Chamisso Prize raises similar ambivalent feelings, as it marginalises as well as celebrates writing by non-native German writers. The main criterion of selection for the award is biographical rather than literary. The aesthetic quality or impact of the writing has only secondary importance. To a certain extent the same counts for the E. du Perron Prize that also awards contributions to the multicultural society rather than aesthetic quality. ${ }^{16}$

Although I fully agree with the general purport of this critique, the judgment requires some adjustment from the perspective of my German-Dutch comparison. As we have seen, "Guest Worker Literature" in the German 1980s flourished (in a very particular and surely discursively restricted way), whereas silence determined the Dutch literary field of that time. A comparison of the two contemporaneous literary fields makes clear that the impact of the IGFL in terms of visibility has been enormous. A Dutch counterpart to the IGFL may have helped overcome the total absence of first generation migrant writing from the Dutch literary scene. And whether in the end and in a particular sense, the exoticist and paternalistic efforts of the Munich Institute have been a good thing. In comparison to the multiculturally rich and productive German literature of the 1980s, the Dutch situation was rather barren. We find no migrant writing, no public interventions and no scholarly debate on the literary position of "guest workers", let alone a search for an adequate terminology for a non-existent phenomenon. ${ }^{17}$ The Netherlands completely missed out on migrants' literary

15 See Sabine Fischer, Moray McGowan, From "Pappkoffer" to Pluralism. On the Development of Migrant Writing in the Federal Republic of Germany, in: David Horrocks, Eva Kolinsky (eds.), Turkish culture in German society today, Providence, Oxford: Berghahn Books, 1996, pp. 1-21; Heidrun Suhr, Ausländerliteratur. Minority Literature in the Federal Republic of Germany, in: New German Critique 46, 1989 (Winter), pp. 71-103; Arlene A. Teraoka, Gastarbeiterliteratur. The Other speaks back, in: Cultural Critique 7, 1987, pp. 77-101.

16 Especially when the laureates are of migrant background - which is not a requirement for this prize - the question of ethnic labelling becomes an issue. In an interview with Wilma Kieskamp in the Dutch national newspaper Trouw the E. du Perron prize winner of 1996, Hafid Bouazza, comments that the award in some way also feels like an affront: "I write because I want to write, not because I have the intention to foster more understanding between the cultures. Please leave off. [...] I am not a social worker" "Ik schrijf omdat ik wil schrijven, niet omdat ik de bedoeling heb om meer begrip tussen de culturen te kweken. Hou toch op. [...] Ik ben geen maatschappelijk werker"). Wilma Kieskamp, Bekroonde Hafid Bouazza gebruikt archaïsch Nederlands in sprookjesachtige verhalen, in: Trouw, 21 January 1997.

17 "Proper" terminology for German literature by writers of non-native German origin is an important discussion topic within German intercultural literary studies. See e.g. Julia Abel, Positionslichter. Die neue Generation von Anthologien der "Migrationsliteratur", in: Text+Kritik. 
reflections during an important phase in Dutch history, its society's cultural and ethnic transformation as a cultural effect of post-war organised labour migration. In terms of cultural memory (and the preservation of multiple perspectives on the past), these literary reflections would without doubt have formed valuable and insightful material.

How can one explain the large time gap between the appearance of migrant writing (or literature of migration) in Germany and the Netherlands? I will turn to the specific socio-political contexts in which "guest workers" could write, and show how a consideration of the salient differences between German and Dutch migration policies throw another light on the migrant voices in the respective literatures.

\section{Comparing Contexts}

Several factors seem to intersect in the situations described above. Obviously, the national, regional, social and educative backgrounds of the labour migrants are important, but these were generally not all too different for the labour migrants coming to Germany and the Netherlands. ${ }^{18}$ Moreover, focussing on one particular national group, for instance the Turkish guest workers present in both countries, could level the differences. ${ }^{19}$ The Dutch and German histories of organised labour migration are quite similar and evolved almost simultaneously. Labour migration was officially furthered in the years between 1955, when the first agreement of this kind was signed between Germany and Italy, and 1973, when the international oil crisis resulted in a complete ban on foreign recruit-

Zeitschrift für Literatur (Sonderband Literatur und Migration) 9, 2006, 6, pp. 233-245; Aglaia Blioumi, "Migrationsliteratur", "interkulturelle Literatur" und "Generationen von Schriftstellern”. Ein Problemaufriß über umstrittene Begriffe, in: Weimarer Beiträge 46, 2000, pp. 595601; Hans-Dieter Grünefeld, Deutsche Literatur oder Literatur in Deutschland? Rezeption und Bedeutung literarischer Texte der Migration, in: Sirene. Zeitschrift für Literatur 14, 1995, pp. 88 104.

${ }^{18}$ For a comparison of labour migration and the situation of migrants in the Dutch and the German context see: Anita Böcker, Kees Groenendijk, Einwanderungs- und Integrationsland Niederlande: Tolerant, liberal und offen?, in: Friso Wielenga, Ilona Taute (eds.), Länderbericht Niederlande. Geschichte - Wirtschaft - Gesellschaft, Bonn: Bundeszentrale für politische Bildung, 2004, pp. 303-361; Tom Duyvené de Wit, Ruud Koopmans, Die politisch-kulturelle Integration ethnischer Minderheiten in den Niederlanden und Deutschland, in: Forschungsjournal Neue Soziale Bewegungen 14, 2001, 1, pp. 26-41; Ruud Koopmans, Paul Statham, How national citizenship shapes transnationalism. A comparative analysis of migrant claims-making in Germany, Great Britain and the Netherlands, in: Revue Européenne des Migrations Internationales 17, 2001, 2, pp. 63-100.

19 The national composition of writers depended very much on the specific bilateral agreements that the respective governments made with countries that provided labour migrants. In fact these agreements co-determine - in a rather arbitrary way - the current make-up of the German and Dutch ethnoscapes. 
ment in both Germany and the Netherlands. At that time, it was still assumed that the "guest workers" would return home - as wishfully manifested by the paradoxical term "guest labour". It soon became clear that this was an illusion.

Germany and the Netherlands responded quite differently to the growing awareness that the "migrants" will be permanently present, and thus enduringly transform the national ethnoscape. The German government refused to perceive the country as one of migration. It even tried to get rid of its foreign worker population by means of a Rückkehrforderungsgesetz (10 October 1983), a law that promoted the voluntary return of unemployed foreign workers to their countries of origin. The Dutch government, on the contrary, dealt with the consequences of both labour migration and - a factor not to be neglected - decolonisation, by both "accepting" the permanent presence of the ethnic minorities and acknowledging the new multicultural character of the Netherlands. As I already mentioned in the introduction to this article, as early as 1983 the Dutch parliament agreed on an inclusive minorities policy laid out in the so-called minderhedennota (minorities amendment), which aimed at improving the legal, social and economic status of ethnic minorities and developing a tolerant multicultural society. A central characteristic of this policy was the idea that ethnic minorities could and should integrate into Dutch society, while "retaining their own identity" ("met behoud van eigen identiteit") - a notion that became a red flag for politicians of the populist right at the start of the new millennium, and by now for any politician who has adopted the "new realist" discourse. ${ }^{20}$

This difference in the German and Dutch attitudes and policies - refusal to accept the changing cultural identity as opposed to official acknowledgement of multiculturalisation - determined the socio-political and cultural climate of the two countries in the 1980s. It appears that the Dutch acceptance of cultural and lingual plurality coincides with the silence of first-generation labour migrants in the dominant host culture and language. Though one would think that an early acceptance of cultural plurality would also foster plurality in literature, including participation and integration of (officially accepted) migrant writers, the opposite is true, at least at first sight.

Is it possible to explain this unexpected outcome by reading the literary phenomenon within its particular socio-political frame? Can it be that the distinct German and Dutch policies of migration also had consequences on the German and Dutch literary fields? The Dutch government's concern with the preservation of the migrants' language and culture valued and supported cultural

${ }^{20}$ For a discussion of the rise of the new realist discourse in the Dutch public arena see Baukje Prins, Voorbij de onschuld. Het debat over integratie in Nederland, Amsterdam: Van Gennep, 2004. Pim Fortuyn is generally considered a forerunner of this kind of discourse, whereas Geert Wilders can be seen as one of its contemporary representatives. 
activities within the migrant culture and in the native language. ${ }^{21}$ Citizens of migrant background were accepted as culturally different, and were encouraged to foster a cultural identity associated with the country and culture of origin. For the various ethnic minority groups, there was neither need nor pressure to enter the dominant cultural field. On the contrary, the government's policy aimed at cultivating minority cultures.

In the same period, Germany lacked a sustained migration policy, let alone a policy supportive of the migrants' own cultures. In fact the socio-political climate of that time was downright dismissive of the possibility of a prolonged presence of the "guest workers". However, the more restrictive monocultural approach appears to have had an unexpected positive effect by encouraging a moderate inclusion of migrants in the dominant culture.

The German situation displays various attempts, both by migrants themselves and by non-governmental initiatives of the German majority culture, to undo the migrants' marginality. Several of the non-governmental efforts to address and include the migrant newcomers ensued from the participants' wish to dissociate themselves from the history of fascism and to contribute to the prevention of another wave of xenophobia. ${ }^{22}$ Migrants' own motivation to actively participate in the host culture mainly resulted from the wish to gain visibility as well as acknowledgement in the host society, as the textual positionings by Biondi and Schami make clear. Both the migrant activities and the non-governmental initiatives targeted a - restricted - position of cultural relevance and acceptance, by either speaking out or by making migrant voices heard in the dominant cultural domain.

\section{Traces of "Guest Worker Literature" in Contemporary Literature of Migration}

Reading the appearance of first generation migrant writing in the context of the distinctive Dutch and German migration policies is only one possibility to explain the striking difference between the German and the Dutch literary fields of the 1980s. Surely several factors on various levels jointly shaped the differences. That these differences in the 1980s had repercussions for the literary field of the 1990s becomes clear when one looks at how writers of migrant background positioned themselves. A remarkable difference catches our eyes, if we

${ }^{21}$ After the 1983 change of Dutch policy, ethnic minority groups were also encouraged and expected to participate in Dutch politics as ethnic minorities. To this end a network of several ethnic advisory boards and participation institutes (inspraakorganen) was established.

${ }^{22}$ See e. g. Helmut Kreuzer, Gastarbeiter-Literatur, Ausländer-Literatur, Migranten-Literatur? Zur Einführung, in: Zeitschrift für Literaturwissenschaft und Linguistik LiLi 14, 1984, 56, pp. 7-11. 
consider, for instance, the Turkish-German writer Feridun Zaimoglu and the Moroccan-Dutch writer Hafid Bouazza. The work of these two writers differs considerably in theme and style, but their appearance (in 1995 resp. 1996) and position in the respective literary fields are quite comparable. Both writers wrestled with the ethnicised prejudices of the literary field and with their stigmatisation and marginalisation as "migrant writers". Both writers actively opposed this marked positioning. However, whereas Bouazza blamed the exoticist desires and othering reading technologies of his Dutch audience ${ }^{23}$, Zaimoglu attacked the writing of his father-generation, the Gastarbeiterliteratur. Both in the introduction to his debut Kanak Sprak (1995) and in his provocative essay "Ali macht Männchen" (1998), he makes the first generation migrant writers responsible for raising and satisfying patterns of exoticism and pity in the German reader. ${ }^{24}$ Their "victim literature" about poor but sweet-hearted "Ali" represents a weepy "Turkish authenticity" that the new literature of migration first has to get rid of. For Bouazza such a problem simply does not exist: there is no writing father-generation.

With this final observation I conclude this article that can - and should - be considered as a plea for comparative research. My analysis has foregrounded some national particularities that appear only as such, as meaningful particularities in an international comparative framework. Only a comparative and contextualised approach to "migrant literature" can note, and subsequently help to explain the discrepancy between the stereotyped visibility of first generation migrant writers in Germany and their complete absence from the literary scene in the Netherlands.

${ }^{23}$ Bouazza vehemently resisted the categories of "migrant writer" and "migrant literature" in several interviews and in his essay Een beer in bontjas, Amsterdam: Prometheus, 2001.

${ }^{24}$ Feridun Zaimoglu, Kanak Sprak. 24 Mißtöne vom Rande der Gesellschaft, Hamburg: Rotbuch Verlag, 1995, and: Gastarbeiterliteratur. Ali macht Männchen, in: Ruth Mayer, Mark Terkessidis (eds.), Globalkolorit. Multikulturalismus und Populärkultur, St. Andrä, Wördern: Hannibal, 1998, pp. $85-97$. 